\title{
PANEMA-VERB JA SELLE GRAMMATILISED KASUTUSED
}

\author{
KAIRIT TOMSON
}

1 esti keele tuumverbi panema polüseemsus pakub rikkalikku uurimisainest. Mahukate eri aegade tekste sisaldavate korpuste loomine on andnud võimaluse hõlpsamalt sõnade eri tähendusi ja grammatiseerumist jälgida. Siinse artikli eesmärk on kirjeldada panema-verbi grammatilisi kasutusi, põhjustamis- ja algusfaasikonstruktsiooni, XVI-XXI sajandist pärit eesti keele näidete põhjal ning selgitada eri tähenduste vahelisi seoseid. Eesmärk on näidata, et panema-verb sobitub kindlatesse kasutusskeemidesse selle enda tähendusest tulenevalt. Panema-verbi analüütilist põhjustamiskonstruktsiooni on varem ajama-ja laskma-põhjustamiskonstruktsiooni kõrval käsitlenud Reet Kasik (2001). Eesti keeles on uuritud ka teiste tuumverbide, nt saama (Habicht, Tragel 2012; Maripuu 2012; Tragel, Habicht 2017), tahtma (Habicht jt 2010), võtma (Habicht jt 2015) ja pidama (Erelt 2001) grammatilisi kasutusi. Eesti keele tuumverbide temaatikat on laiemalt käsitlenud Ilona Tragel (2003). Panema-verbi grammatilised tähendused paigutuvad ühtsesse tähendusvõrgustikku koos selle verbi leksikaalsete tähendustega. Puudutan põgusalt ka leksikaalseid tähendusi, et tähendusseosed nende kaudu terviklikumalt esile tuua. Panema-verb väärib uurimist ühena neist verbidest, mis võimaldavad oma grammatiseerumistee ja mitmekesiste kasutusjuhtudega keele rikkust ja keeles toimuvaid tähendus- ja funktsioonimuutusi laiemalt hoomata.

Panema-verbi loetakse tuumverbiks, kuna see vastab kindlatele kriteeriumidele: verbi polüseemsuse kõrval on nendeks grammatiline funktsioon, üldmõistelisus, sagedus ja varane omandamine (Tragel 2003). Polüseemse sõna eri tähendused on seotud selle keskse tähendusega (Ravin, Leacock 2000). Panema-verbi keskseks tähenduseks pean asetamistähendust: see on kogu uuritud perioodil esinenud kõige sagedamini (Tomson 2014, 2016) ja on mitmetes eesti keele sugulaskeeltes esimesena nimetatud tähendus (EES 2012: 351-352).

Panema-verbi grammatiseerumisprotsess on seni kätkenud endas tähenduse arengut, milles panema on kaotanud (osaliselt) keskse asetamistähenduse ning moodustab sellisena koos teiste konstruktsiooni komponentidega põhjustamist või alustamist väljendava tähendusliku-vormilise terviku (Tomson 2014, 2016). Nii väljendab näiteks konstruktsioon ta paneb muusika mängima (MõjUTAJA + panema + MõJUTATAV $+\mathrm{V}_{\text {ma-inf }}$ ) põhjustamist ja ma panin plagama (AGENT + panema $+\mathrm{V}_{m a-i n f}$ ) alustamist. Panema-verbi grammatiline kasutus on vastavuses Adele Goldbergi (1995) konstruktsioonigrammatika käsitlusega, mille järgi ei ole konstruktsiooni kui vormi ja tähenduse tervikliku paari mingi vormi või tähenduse aspekt täielikult ennustatav selle konstruktsiooni üksikute komponentide põhjal. 
Panema-verbi grammatiliste konstruktsioonide kujunemise kõrval pakub sajanditepikkuse perioodi materjal näiteid mitmete verbiühendite tähenduse kujundlikumaks muutumisest. Näiteks ei väljenda verbiühend kinni panema üksnes mingi objekti sulgemist, vaid ka vangistamist. Samuti on üksikud panema-verbiühendid kasutusest kadunud (nt muresse panema) või kaotanud kunagise tähenduse (nt enam ei panda toime üritusi, vaid kuritegusid). Ülekandelise tähendusega on ka mitmed viimastel aastakümnetel lisandunud kasutusjuhud, nt ühendverb ära panema, milles panema-verb annab ühendile hinnangulise väljendusrikkuse. Selline ekspressiivsuse väljendamine panemaverbiga on viimase aja märgatavaimaks tähenduse arenguks. (Tomson 2016)

Artikkel kirjeldab seega korpusmaterjali põhjal panema-verbi kasutuse terviksüsteemi ja keskendub selle taustal grammatiliste tähenduste seostele leksikaalsete tähendustega. Artikli eesmärk on avada panema-verbi põhjustamis- ja alustamiskonstruktsiooni tähendust ja vormi ning tuua välja nende konstruktsioonide sagedus ja koht panema-verbi tähendusvõrgustikus. Sellise mahuga kasutuspõhist analüüsi ei ole panema-verbi kohta varem tehtud.

Järgmises jaotises esitan teoreetilised lähtekohad ning selgitan artikli põhimõisteid. Metoodika osas annan ülevaate materjali mahust, iseloomust ja uurimise käigust. Kolmandas jaotises käsitlen panema-verbi leksikaalseid ja grammatilisi tähendusi, neljandas tutvustan panema-verbiga kaasnevat ekspressiivsust ning viiendas osas selgitan tähendusseoseid.

\section{Teoreetilised alused ja põhimõisted}

Panema-verbi kasutusest tervikliku pildi saamiseks tuleb ühendada mitu teoreetilist lähtekohta. Konstruktsioonigrammatikas tuginen Adele Goldbergi (1995) käsitlusele, kes nimetab konstruktsiooniks vormi ja tähenduse lahutamatut kooslust. Lähtun artiklis mitmest konstruktsiooniga seotud mõistest. Iga konstruktsioon koosneb eri komponentidest, mis tervikuna väljendavad mingit tähendust. Panema-põhjustamiskonstruktsiooni komponendid on kaheosaline predikaat, MõJutaja ${ }^{1}$ ja MõJutatav, mis tervikuna väljendavad millegi põhjustamist. Verb sobitub konstruktsiooni selle konstruktsiooni terviktähenduse põhjal (Goldberg 1995: 11-13). Konstruktsioonitüüp eristab konstruktsiooni all-liike vastavalt selle komponentide semantilistele rollidele. Konstruktsioonitüüpide esitamiseks kasutan Pille Penjami töö (2008) vormistust. Ta on $m a$ - ja $d a$-infinitiivsete konstruktsioonide seas käsitlenud ka põhjustamiskonstruktsiooni.

Panema-verbi grammatilisemaks muutumist vaatlen grammatisatsiooniteooriast lähtuvalt. Selle kohaselt areneb grammatiline keeleüksus leksikaalsest ning muutub arengu käigus järjest grammatilisemaks. (Heine, Kuteva 2002) Grammatiseerumisprotsessi vormilist arengut kujutatakse ahelana TÄISTÄHENDUSLIK SÕNA > GRAMMATILINE SÕNA > KLIITIK > MUUTEAFIKS > $\varnothing$, üheks selliseks arenguks on ka abiverbi kujunemine täistähenduslikust verbist (Hopper, Traugott 1993: 7, 108-109). Abiverbe iseloomustab see, et need ei ole lau-

${ }^{1}$ Konstruktsiooni komponendid (Mõjutaja, Mõjutatav ja Tulemussituditsioon) on artiklis tähistatud suure algustähega, semantilised rollid (AGENT, JÕUD, KOGEJA, PATSIENT, TEEMA, SEISUND, TEGEVUS, SOORITUS, SAAVUTUS ja PROTSESS) eristuse mõttes mitte. 
ses iseseisvalt öeldised ning neil ei ole enam leksikaalset tähendust, vaid on kategoriaalne staatus. Abiverb võib käituda muus süntaktilises ümbruses ka põhiverbina. (Heine 1993: 22-24) Kausatiivsed poolabiverbid panema, ajama, saama ja laskma väljendavad infinitiiviga ahelverbi moodustades üldist põhjustamistähendust. Need verbid pole sisult iseseisvad, vaid esinevad koos täistähendusliku lekseemiga. Perifrastilised kausatiivid moodustavad siiski vaid lõdva liitpredikaadi. (Erelt 2013: 212-213) Grammatiseerumisahelas on panema-verb põhjustamistähenduse väljendajana grammatilise sõna staadiumis.

Panema-verbi tähendusi saab käsitleda ühtses tähendusvõrgustikus, lähtudes polüseemia põhimõtetest. Analüüsi aluseks olen võtnud Yael Ravini ja Claudia Leacocki (2000) käsitluse põhiidee, mille kohaselt polüseemse sõna tähendused on seotud selle keskse tähendusega. Sellist seost on näha ka sõna grammatilisi kasutusi uurides. „Maailma keelte grammatiseerumise leksikonis" on panema-verbiga seoses nimetatud ainult lõpetamisele / teostatud tegevusele osutavat kompletiivi tähendust, näitena on toodud paapua imonda keel (Heine, Kuteva 2002: 248). Kompletiivi samastatakse osas käsitlustes perfektiivse aspektiga (nt Matthews 1997: 64, 271). Kausatiivi „Maailma keelte grammatiseerumise leksikonis" panema-verbi tähendusena nimetatud pole. Teistes keeltes on perifrastilises kausatiivis kasutusel näiteks verbid tegema, saama ja omama. Polüseemsusega kaasneb sõna kujundlik tähendus, mida ka panema-verbi uurimine esile toob.

\section{Materjal ja meetod}

Artikkel põhineb kahel uurimusel (Tomson 2014, 2016), milles analüüsisin kokku ligikaudu 3800 panema-verbi kasutusjuhtu. Neist varasem uurimus käsitles panema-verbi kasutust XVI-XVIII sajandi (umbes 740 kasutusjuhtu), hilisem XIX-XXI sajandi kirjakeeles (umbes 3060 kasutusjuhtu). Et materjal on kogutud tegelikust keelekasutusest, siis paigutub uurimus kasutuspõhise keelekäsitluse raamistikku (nt Barlow, Kemmer 2000).

Tabel 1.

Analüüsitavate panema-verbi kasutusjuhtude hulk

\begin{tabular}{cccccc}
\hline $\begin{array}{c}\text { XVI-XVII } \\
\text { sajand }\end{array}$ & $\begin{array}{c}\text { XVIII } \\
\text { sajand }\end{array}$ & $\begin{array}{c}\text { XIX } \\
\text { sajand }\end{array}$ & $\begin{array}{c}1890 .-1990 . \\
\text { aastad }\end{array}$ & $\begin{array}{c}\text { Tänapäev } \\
\text { (alates } \\
\text { aastast } \\
\text { 2000) }\end{array}$ & Kokku \\
& & & & & \\
\hline
\end{tabular}

Analüüsitavate kasutusjuhtude

$\begin{array}{lllllll}\text { arv } & 249 & 494 & 484 & 1631 & 490(+500) & 3848\end{array}$

Materjali valikul arvestasin, et analüüsitavad panema-verbi kasutusjuhud kuuluksid erinevatesse tekstiliikidesse. Korpusmaterjal sisaldab religioosseid, teaduslikke, ajakirjandus- ja ilukirjandustekste ning internetikeelt. Uurimuse XVI-XVIII sajandi panema-verbi kasutusjuhud on pärit Tartu Ülikooli vana kirjakeele korpusest (VAKK), XIX-XXI sajandi näitelaused VAKK-ist, eesti 
kirjakeele korpusest (1890., 1910., 1930., 1950., 1970. ja 1990. aastatest) ning eesti keele ühendkorpusest (koosneb veebikorpusest etTenTen, tasakaalus korpusest ja koondkorpusest). Tabelis 1 on kirjas, kui palju eri kasutusjuhte millisest sajandist analüüsisin.

Esimeseks eesmärgiks oli määrata igale panema-verbi kasutusjuhule tähendus ning jagada tähendused rühmadeks. Suurem osa kasutusjuhtudest jagunes selgepiirilistesse tähendusrühmadesse, aga mõnel juhul ei olnud tähenduse ebamäärasuse tõttu võimalik kasutusjuhtu kindlasse tähendusrühma paigutada. Mitmetise tähendusega näidete jaoks moodustasin sildkonstruktsioonide rühmad. Sildastmena (ingl bridging stage) käsitletakse grammatiseerumisprotsessis astet, millel lingvistilise elemendi tuumtähendusele lisandub uues kontekstis lisatähendus (Heine, Kuteva 2006: 327). Näiteks väljendab sildkonstruktsioon soola panema ühelt poolt asetamist ja teiselt poolt sooldumise protsessi põhjustamist (vt sildkonstruktsioonide kohta jaotist 5). Tähendusrühmi ilmestavad artiklis nummerdatud näitelaused, mis on pärit materjalist muutmata kujul. Lisaks esinevad tekstisisesed näited (enamasti lühendatud kujul), et kirjeldatut hõlpsalt ja mitmekesisemalt näitlikustada.

Struktuuriliselt on määratud, kas panema-verb esineb lihtverbina (nt panen toidu lauale), ühend- (nt kaant peale panema) või väljendverbi (nt paneme hoolikalt tähele), tugiverbikonstruktsiooni (nt pidu panema) või grammatilise konstruktsiooni (nt ta paneb lapsed end kuulama) ühe osalisena. Materjalis eristusid ka fraseoloogilised tervikud, nagu kõrva taha panema, naelapea pihta panema ja ôlga alla panema. Panema-verbi püsiühendid (mis kannavad tervikuna omaette tähendust, nt tähele panema 'märkama' või eespool mainitud kinni panema 'vangistama') on tähendusrühmade sees eraldi esitatud.

XIX-XXI sajandi tekstide kohta tehtud uurimuses kasutasin ka korpuspäringusüsteemi Sketch Engine (Kilgarriff jt 2004), mille kaudu on võimalik leida sagedusandmeid ülisuure näidete arvu põhjal. Seda päringusüsteemi kasutasin kahel eesmärgil: esiteks selleks, et täiendada eelnevalt kirjeldatud meetodiga leitud verbiühendite loetelu; teiseks, et vaadata lähemalt grammatiliste konstruktsioonide osaliste sagedusandmeid. Näiteks võimaldab Sketch Engine sageduse järgi reastada panema-verbi grammatilistes konstruktsioonides esinevad ma-infinitiivsed tegusõnad (nt see paneb teda imestama).

Põhjustamiskonstruktsiooni analüüsisin selle osaliste semantiliste rollide ning vormi põhjal. Semantilise rolli määrasin MõJutajale, Mõjutatavale ja Tulemussündmusele ehk Tulemussituatsioonile. Vormiliselt esines MõjutaTAVA varieeruvust: kes/mis võib olla nominatiivi, genitiivi või partitiivi vormis. Analüüsitavaid põhjustamiskonstruktsioone oli 458. Lugesin kokku erinevad semantiliste rollide kombinatsioonid ning esitasin sagedasemad konstruktsioonitüübid tähenduse-vormi paaridena.

Enne panema-verbi kasutuste täpsemat kirjeldamist järgmistes jaotistes on joonisel 1 esitatud ligikaudne grammatiliste kasutuste (põhjustamis- ja alustamiskonstruktsiooni) osakaalu suhe leksikaalsete kasutuste ning sildkonstruktsioonidega. 


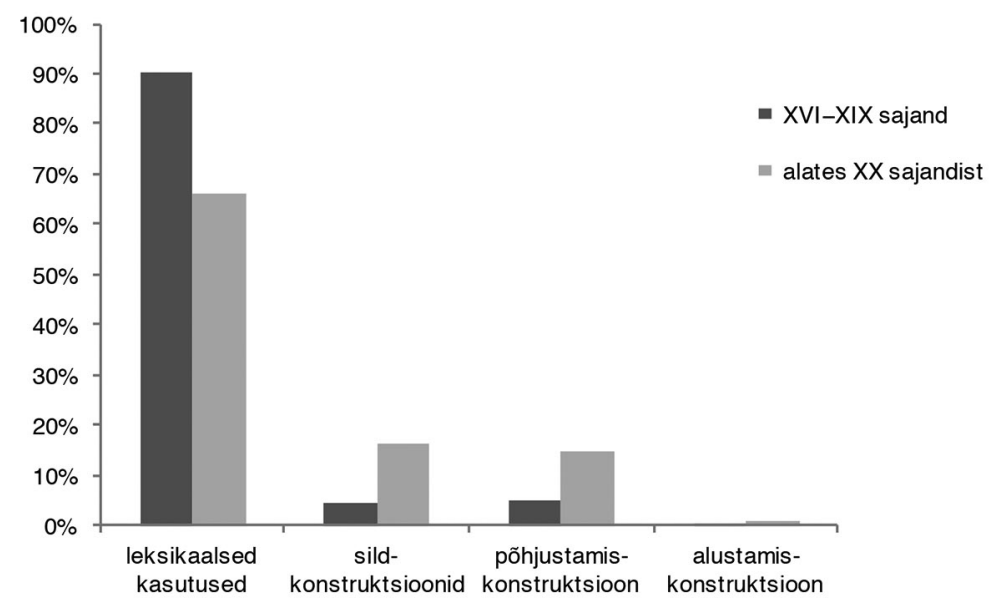

Jo on is 1. Panema-verbi leksikaalsete ja grammatiliste kasutuste osakaal XVIXIX sajandil ja XX-XXI sajandil.

Joonisel 1 on võrdlevalt esitatud kahe ajajärgu sagedusandmed. Kujutatud tulpade paarist esimene näitab horisontaalteljel nimetatud rühma osakaalu (leksikaalsed kasutused, sildkonstruktsioonid ning põhjustamis- ja alustamiskonstruktsioonid) kõikidest kasutusjuhtudest XVI-XIX sajandil. Teine tulp näitab vastava rühma osakaalu XX-XXI sajandil. Laiemal tõlgendamisel oleks osa sildkonstruktsioonidest võimalik paigutada kujundlike leksikaalsete kasutuste rühma, mistõttu ei ole sildkonstruktsiooni tulbad muu materjaliga rangelt võrreldavad. Olulisim on siinkohal rõhutada, et sildkonstruktsioone esineb mõlemal vaadeldaval perioodil. Grammatiliste kasutuste kohta on jooniselt näha, et ehkki neid on tunduvalt vähem kui leksikaalseid, on põhjustamiskonstruktsioonil panema-verbi kõikide kasutuste lõikes siiski märgatav osa. Grammatilistest konstruktsioonidest on põhjustamiskonstruktsioon tunduvalt sagedasem kui alustamiskonstruktsioon.

\section{Panema-verbi tähendused eesti kirjakeeles}

Leksikaalsete tähenduste alla kuuluvad need kasutusjuhud, kus verb ise kannab põhitähendust. Arvestada tuleb siiski panema-verbi kasutuste kujundlikkusega, näiteks kui amet pannakse maha, siis ka selles näites asetatakse midagi kuhugi. Kujundliku tähendusega kasutusjuhud on jagatud laiematesse leksikaalsetesse tähendusrühmadesse, lähtudes sellest, millisest füüsilise paigutamise tähendusest ('asetama' või 'teise asendisse seadma') need on motiveeritud. Eesti keele öeldisverbi grammatilises vormis avalduvad muu hulgas aja ja aspekti tähendus (Erelt 2013: 66). Lisaks $m a$-infinitiivi sisaldavatele konstruktsioonidele vaatlen ka teistsuguse vormiga konstruktsioone, millel on samuti grammatiline tähendus (vt jaotis 3.2.2). 


\subsection{Leksikaalsed tähendused}

Panema-verbi leksikaalsed tähendused on jaotatud nelja rühma: 1) 'asetama', 2) 'määrama', 3) 'teise asendisse seadma', 4) 'kellekski/millekski/mingisuguseks arvama, pidama'. Need leksikaalsed tähendused on loetletud ka „Eesti keele seletavas sõnaraamatus" (EKSS: 75-76), ehkki osa sealsete rühmade all nimetatud näiteid on siinse uurimuse tähendusvõrgustikus käsitletud sildkonstruktsioonide rühma kuuluvana (nt likku panema ja rakkesse panema). EKSS-is (2009: 76-79) on eraldi välja toodud ka mitukümmend panema-verbi püsiühendit.

Panema-verbi kõige sagedamini esinev tähendus on asetamistähendus, st ruumis asetatakse (ka kujundlikult) kusagile mingi objekt. Läbi sajandite on selles tähenduses esinenud ligikaudu pool kõikidest panema-verbi kasutusjuhtudest: XVI-XVII sajandil $\sim 47 \%$, XVIII sajandil ja XIX sajandi I poolel $\sim 63 \%, 1890 .-1990$. aastatel $\sim 47 \%$ ja alates aastast $2000 \sim 46 \%$. Lihtverbilise kasutuse kõrval (nt pani dokumendid lauale (näide 1)) leidub mitmesuguseid väljendverbe (nt selga panema) ja ühendverbe (nt alla panema). Panema-verb võib tänu oma ekspressiivse kasutuse võimalusele asendada ka teisi verbe, mis seostuvad asetamistähendusega (vt ekspressiivsete kasutuste kohta jaotist 4).

(1) See, tõusmata toolilt, pani lauale oma dokumendid [---] (AJA 1950)

Mõnest algselt asetamistähendusega verbiühendist on välja kasvanud ülekandelise tähendusega verbiühend või -ühendid. Näiteks tähendab ühend ette panema otseses tähenduses millegi asetamist kellegi ette, aga ülekandeliselt ettepaneku tegemist või nõude esitamist (nt võib komisjon panna ette seaduseelnõu väljatöötamise või valitsus panna ette lõpetada sõjategevus).

Asetamistähendusest kitsama rühma moodustavad sellised kasutusjuhud, milles ei muudeta objekti asukohta, vaid asendit (ka olukorda või seisundit). Kõige tüüpilisem selle rühma näide on kinni panema (näiteks ust kinni panema (näide 2), aga ka kedagi kinni panema 'vangistama' või aega kinni panema). Samuti võib midagi nt kokku, risti või püsti panna.

(2) Jah, päris tõesti, ma panen ukse kähku kinni. (ILU 1930)

Määramistähendusest võib rääkida seoses kellegi ametisse määramisega (nt rügemendiülemaks panema, näide 3), otsustamisega (nt hinnet panema), (omaks) andmisega (nt nimeks panema), kellelegi millegi negatiivse õlule panemisega (nt vaeva kellegi peale panema) ja kellelegi mingi funktsiooni andmisega (nt pandiks panema). Neis näidetes on olemas tahteline agent, kes millegi üle otsustab. Määramistähendus on asetamistähenduse kõrval teine leksikaalne tähendus, mis polüseemse panema-verbi põhjustamistähendusega kaasneb. Paljudes näidetes on põhjustaja ühtlasi agendiline määraja, nt on lauses Ta paneb vee keema põhjustajaks ta.

(3) Kuid juba esimeses lahingus sai ta haavata ja rügemendiülemaks pandi major Maitla. (AJA 1990) 
Eraldi leksikaalne tähendusrühm on 'kellekski/millekski/mingisuguseks pidama, arvama'. Siia kuuluvad mõned kindlad ühendid, nagu pahaks või halvaks panema, aga sellesse konstruktsiooni võib paigutada igasuguseid nimisõnu, nt koeraks panema (st mingit inimest võrreldakse koeraga, näide 4). Kui XIX sajandi I poolel oli selles tähenduses kasutusjuhte 9,7\%, siis 2000. aastate kasutusnäidete hulgas vaid 0,4\%. Ehkki mõned kindlad ühendid, nt pahaks panema, ei ole keelekasutusest kadunud, on see tähendus üldiselt hakanud vähenema.

(4) „Et sa mind, kes ma ollen ilmasüta mees, koeraks paned” ütles Kappar melest waewatud, „sedda andko Jummal sulle andeks, ni kui minnagi sulle annan.” (VAKK, Schüdlöffel 1843)

\title{
3.2. Grammatilised kasutused
}

\subsubsection{Panema-põhjustamiskonstruktsioon ja selle tüübid}

Panema-põhjustamiskonstruktsiooni näited koonduvad järgneva skeemi alla:

\begin{abstract}
Mõjutaja (nominatiiv) + PANEMA-VERB (vormipiiranguid pole) + MõJutatav (nominatiiv, genitiiv, partitiiv) + Tulemussituatsioon ( $m a$-infinitiiv)
\end{abstract}

Konstruktsiooni kuulub Mõjutaja, panema-verb, Mõjutatav ja Tulemussituatsioon. Mõjutaja põhjustab Mõjutatavaga toimuva sündmuse. Näiteks on lauses See fakt pani ta tõsiselt mõtlema Mõjutajaks see fakt, MõJutatavaks ta ja Tulemussituatsiooniks mõtlema. Nii on ühendatud põhjustamissündmus (eelnevas näites fakt paneb) ja tulemussündmus ( $t a$ mõtleb). Mõne konstruktsiooni juures esineb ka kohaargument, aga vaid üksikutel juhtudel muudab kohaargumendi puudumine sündmuse põhisisu, nt kui keegi pannakse nurka seisma. Enamikul juhtudest lisab kohaargument lihtsalt täpsustavat infot: nt lauses Suur Jummal panneb päikest paistma Ma ja merre peale (VAKK, Schüdlöffel 1843).

Esimene põhjustamiskonstruktsiooni näide analüüsitud materjalis pärineb August Wilhelm Hupeli 1766. aasta teosest „Lühhike öppetus”. Kirjakeelde ilmudes oli panema-põhjustamiskonstruktsioon varieeruv. Näidetes panne neid ülles kuiwama (VAKK, Hupel 1766) ja panne isse ommad käed tööle (VAKK, Willmann 1782) erineb objekti kääne ja tulemussündmuse semantiline roll. Ommad käed on täisobjekt, neid on osaobjekt. Kuiwama on PROTSESs, tööle on TEGEvUs. Varieeruvuse põhjal võib oletada, et suulises keeles oli põhjustamiskonstruktsioon olemas juba enne XVIII sajandit. Põhjustamistähenduses näidete võrdlemine saksa keelega Wiedemanni sõnaraamatus (1923: 764, esimene trükk 1869) leiduvate näidete põhjal lubab teha järelduse, et eesti keele panema-põhjustamiskonstruktsioon ei ole üle võetud saksa keelest. Sõnaraamatu näidetes on näha, et eesti keele panema-verbi asemel on saksa keeles kasutatud erinevaid verbe, nt lugema panema - sks lesen lassen, käima panema - sks in Gang bringen ja seisma panema - sks hinstellen. Tõenäoliselt 
on panema-põhjustamiskonstruktsioon eesti keelele endale omane. Kui XVIII sajandil oli põhjustamiskonstruktsiooni kasutusi vähe $(\sim 2 \%)$, siis XIX sajandi I poolel juba $\sim 9 \%$, sealt edasi kuni tänapäevani 13-15\%.

Järgnevalt selgitan põhjustamiskonstruktsiooni tüüpide määramise aluseid ja seejärel käsitlen lähemalt nelja sagedasemat konstruktsioonitüüpi. Esitan need vormi ja tähenduse paaridena (Goldberg 1995) ja kirjeldan neid mõne Robert Dixoni põhjustamiskonstruktsiooni semantikas eristatud parameetri põhjal. MõJuTAJA puhul saab otsustada tema tegevuse otsesuse, loomulikkuse, kavatsuse ja tulemussündmusega seotuse üle. MõJutAtava kohta saab kirjeldada temale osutatud mõjutatuse tugevust, tahet sündmust sooritada ja võimet sündmust kontrollida. (Dixon 2000: 62)

Semantiliste osaliste mõttes varieerub põhjustamiskonstruktsioon palju. Semantilisi rolle põhjustamiskonstruktsiooni analüüsi jaoks ei ole valitud ühest kindlast teooriast, vaid mitme autori käsitlustele toetudes (Kasik 2015; Pajunen 1999; Van Valin 2001; Vendler 1957) moodustasin panemapõhjustamiskonstruktsiooni jaoks sobivaima liigituse. MõJUTAJA on AGENT või Jõud, Mõjutatav on Kogeja, PATSIEnt või TEema ja Tulemussündmus on SEISUND, TEGEvUs, sooritus, SAAVutus või PROTSEss. AGEndina käsitlen tahteliselt tegutsevat elusolendit või elusolendite rühma, JõUKs loen loodusnähtusi, füüsilisi objekte ja abstraktseid nähtusi. MõJutATAVA semantiliste rollide määratluses tuginen Van Valinile (2001), kelle järgi on PATSIENT mingis seisundis või seisundimuutuses olev entiteet, TEEMA on seotud entiteedi mingis asukohas olemise või asukohamuutusega ning KOGEJA entiteedi taju, tunnetuse ja emotsioonidega.

Toon välja paar iseloomulikumat asjaolu nende semantiliste rollide esinemisel põhjustamiskonstruktsioonis. Jõud võib ühe sõna või sõnaühendiga väljendamise kõrval (nt tuul, ravim, kartus) olla esitatud ka pikemalt väljendatud asjaoluna. Näites 5 põhjustab arvamise asjaolu, et mitmeid kordi saadeti ta asumisele, aga ta põgenes sealt imelihtsasti. Sellele asjaolule viitab asesõna mis. Näites 6 põhjustab ehmatamise aga see, et mesikäpp pääses rahva käest eluga, ning see asjaolu võetakse kokku asesõnaga see.

(5) Mitmeid kordi saadeti teda asumisele, aga ta põgenes sealt imelihtsasti, mis paneb ajaloolasi arvama, et tal olid ka suhted kaitsepolitseiga. (Tasakaalus korpus)

(6) Et Messikäp elloga rahwa käest peasnud, se ehmatas rebbast ja panni ta süddant paisoma. (VAKK, Kreutzwald 1850)

Tulemussündmuse verbide liigitamisel kasutasin Zeno Vendleri (1957) situatsioonitüüpide jaotust, mis sobib põhjustamiskonstruktsiooni tüüpide esitusse oma võrdlemisi laia üldistusastme poolest. Vendleri neljasele jaotusele (SEISUNDID, TEGEVUSED, SAAVUTUSED ja SOORITUSED) lisasin PROTSESSI kategooria. Ehkki Vendleri situatsioonitüüpide põhiliigituses PROTSESSI ei ole, nimetab ta seda oma selgitustes TEGEVUSTE ja SOORITUSTE kohta. SAAVUTUSI ja SOORITUSI on võrreldes teiste semantiliste rollidega panema-põhjustamiskonstruktsioonis vähe. Kas nende vähesus võib olla tingitud asjaolust, et SAAvUTUsi ja sooRITUSI ongi situatsioonitüüpidena üldiselt vähem, või sellest, et resultatiivsed sündmustüübid ei kipu kausatiivsete konstruktsioonidega kombineeruma, 
jääb siinses artiklis veel vastuseta. Miski muu peale sAAvUTUste ja soorituste vähesuse panema-põhjustamiskonstruktsioonis ei viita sellele, et SAAVUTUSED ja sooritused sellesse konstruktsiooni ei sobituks. Detailsete verbiliigituskriteeriumide seast toon välja mõne põhilisema. TEgEvusi (nt mängima) ja PROTSESSE (nt suurenema) eristasin selle põhjal, et tüüpilistel PROTSESSIDEL on tulemuseks mingi asi või omadus. Seisundites (nt uskuma) ei väljendu muutust. SOORITUSED (nt kokku kaapima) on tegevused, mis lõpevad tulemusega, SAAVUTUSED (nt võitma) on aga tulemusele joudmise hetkelised sündmused.

Sketch Engine'i abil ilmnes, et kõige sagedasemad TulEmussituATsiooni verbid on mõtlema ja imestama ning mõtlema panema ei jää sageduselt kaugele ka kõige sagedamini esinevatest leksikaalsetest kirja panema ja tähele panema ühenditest. Sketch Engine'i päringutulemustes esildusid sagedatena ka ühendid maksma panema 'kehtestama' ja käima panema 'käivitama'. Teisi $m a$-infinitiivseid ühendeid koos panema-verbiga esineb materjalis harvem. Neist mitmetise tähendusega on ühend hakkama panema 'ära raiskama' või 'ära sööma / jooma' või 'millekski/midagi valmis seadma'.

Kõiki analüüsitud materjalis esinevaid põhjustamiskonstruktsiooni juhte ei saanud sagedasemate tüüpide esitamisel arvesse võtta, kuna mõnes kasutusjuhus pole kõiki semantilisi osalisi nimetatud, näiteks pole umbisikulise tegumoe puhul nimetatud mõjutajat. Nende kasutusjuhtude põhjal aga, mida sai arvestada (458), moodustus semantilistest rollidest 21 erinevat konstruktsioonitüüpi. Tabelis 2 on esitatud sagedasemad konstruktsioonitüübid koos sagedusandmete ja kasutusnäidetega. Näitelauseid on võrreldes tegeliku materjaliga mõnevõrra lihtsustatud, et konstruktsiooni kesksed osalised selgemalt esile tuua.

Tabel 2.

Kümme sagedasemat konstruktsioonitüüpi

\begin{tabular}{lcc}
\hline Konstruktsioonitüüp ja kasutusnäide & $\begin{array}{c}\text { Esinemissagedus } \\
\text { absoluutarvudes }\end{array}$ & $\begin{array}{c}\text { Esinemissagedus } \\
\text { protsentides }\end{array}$ \\
\hline $\begin{array}{l}\text { AGENT-PATSIENT-PROTSESS } \\
\text { Ma panen vee keema. }\end{array}$ & 72 & 15,7 \\
\hline $\begin{array}{l}\text { JÕUD-PATSIENT-PROTSESS } \\
\text { Ohk paneb põsed punetama. }\end{array}$ & 68 & 14,8 \\
\hline $\begin{array}{l}\text { AGENT-PATSIENT-TEGEVUS } \\
\text { Oppetaja paneb lapsed lugema. }\end{array}$ & 58 & 12,7 \\
\hline $\begin{array}{l}\text { AGENT-PATSIENT-SEISUND } \\
\text { Ratsanik pani hobuse end austama. }\end{array}$ & 55 & 12 \\
\hline JÕUD-PATSIENT-SEISUND & 37 & 8,1 \\
See teema pani vaimu särama. & 32 & 7 \\
\hline JÕUD-KOGEJA-SEISUND & & 7 \\
Olukord pani ta muretsema. & 32 & 4 \\
\hline JÕUD-PATSIENT-TEGEVUS & 18 & 3,7 \\
Seinapilt paneb inimesed selle üle arutama. & & \\
\hline JÕUD-PATSIENT-SAAVUTUS & 17 & \\
Hirm paneb teda üles tunnistama. & & \\
\hline AGENT-TEEMA-SEISUND & & \\
Kohus pani asja seisma. & & \\
\hline
\end{tabular}


AGENT-KOGEJA-SEISUND

Ta pani mind endasse uskuma.

13

2,8

\begin{tabular}{lrc}
\hline Muud & 56 & 12,2 \\
\hline Kokku & 458 & 100
\end{tabular}

17 konstruktsiooni esinemissageduse osakaal on alla kümne, järgnevalt esitatud nelja tüübi esinemissagedus aga üle kümne protsendi. Artikli mahu piiratuse tõttu esitan siin vaid sagedasemad konstruktsioonitüübid.

Kõige sagedamini (15,7 \%) esineb materjalis sellist tüüpi konstruktsiooni, milles AGENT põhjustab PATSIENDIGA toimuva PROTSESSI. AGENT käivitab protsessi tahtlikult, aga tavaliselt ise tulemusprotsessis ei osale.

\begin{tabular}{|c|c|c|c|c|}
\hline VORM & $\underline{\text { subjekt }}$ & $\mathbf{V}_{1}^{\text {panema }}$ & objekt & $V_{2}^{m a}$ \\
\hline TÄHENDUS & agent & põhjustama & patsient & protsess \\
\hline NÄIDE & $\underline{\mathrm{Ma}}$ & panen & vee & keema. \\
\hline
\end{tabular}

14,8 \% kasutusjuhtudest on PROTSESSI põhjustaja JõUD, ent JõUD ise, nagu eelneva konstruktsioonitüübi AGENT, põhjustatud PROTSESSIST enamasti osa ei võta. Kuna Jõud on olemuselt iseeneslik, siis PROTSESSI toimumiseks ei tehta pingutusi. Olenevalt Jõu tugevusest on PATSIENT suuremal või vähemal määral sunnitud JõU mõjule alluma.

\begin{tabular}{|c|c|c|c|c|}
\hline VORM & $\underline{\text { subjekt }}$ & $\mathrm{V}_{1}^{\text {panema }}$ & objekt & $V_{\mathbf{2}}^{m a}$ \\
\hline TÄHENDUS & jõud & põhjustama & patsient & protsess \\
\hline NÄIDE & Õhk & paneb & põsed & unetam \\
\hline
\end{tabular}

12,7 \% kasutusjuhtudest põhjustab AGENT PATSIENDI teostatava TEGEVUSE. PATSIENT, kes on nendes näidetes enamasti inimene, saab mõnel määral AGENDI mõju kontrollida. PATsiendil ei pruugi olla tahet sunnitud tegevust teha.

$\begin{array}{lllll}\text { VORM } & \underline{\text { subjekt }} & \mathbf{V}_{\mathbf{1}}^{\text {panema }} & \underline{\underline{\text { objekt }}} & V_{\mathbf{2}}^{\text {ma }} \\ \text { TÄHENDUS } & \underline{\text { agent }} & \text { põhjustama } & \underline{\text { patsient }} & \text { tegevus } \\ \text { NÄIDE } & \underline{\text { Oppetaja }} & \text { paneb } & \underline{\text { lapsed }} & \text { lugema. }\end{array}$

AGENT saab PATSIENDi ka mingisse SEISUNDISSE viia (12\% kasutusjuhtudest). AGEnT ise selles tulemussündmuses ei osale. Siia rühma kuulub ka sageli esinev maksma panema 'kehtestama' ühend (nt kord pannakse maksma 'kord kehtestatakse').

$\begin{array}{lllll}\text { VORM } & \underline{\text { subjekt }} & \text { V panema } & \underline{\text { objekt }} & V_{\mathbf{2}}^{\text {ma }} \\ \text { TÄHENDUS } & \underline{\text { agent }} & \text { põhjustama } & \underline{\text { patsient }} & \text { seisund } \\ \text { NÄIDE } & \underline{\text { Ratsanik }} & \text { pani } & \underline{\underline{\text { hobuse }}} & \text { (end) austama. }\end{array}$


Seega võib välja tuua sagedamini esinevaid konstruktsioonitüüpe ja esile tõsta panema-põhjustamiskonstruktsiooni suurt (semantilist) varieeruvust.

Kui jätta eristamata TulEMUSsituATSIOONI tüübid, siis esineb kõige rohkem AGENT-PATSIENT (41\%) ja JõUd-PATSIENT tüüpi (35\%) konstruktsioone. See näitab, et objekt (MõJUTATAV) on panema-põhjustamiskonstruktsioonis enamasti PATSIENT, aga KOGEJA ja TEEMA tüüpi objekte esineb kumbagi vaid $12 \%$ kõigist kasutusjuhtudest. Subjekti (MõJUTAJA) semantiline roll on umbes pooltel kasutusjuhtudest AGENT ja pooltel juhtudest JÕUD. Kaasates aga TulemussituatSiOONI tüübid, ilmneb, et TulEMUssituatsooni tüüp ei ole seotud ainult ühes kindlas semantilises rollis subjekti ja objektiga. Sagedasemad situatsioonitüübid (PROTSESS, SEISUND ja TEGEVUS) esinevad koos mitmesuguste subjektiobjekti kombinatsioonidega.

\subsubsection{Panema-alustamiskonstruktsioon}

Panema-verb kuulub faasiverbide hulka. Mõned faasiverbid, nagu pistma, kukkuma ja ka panema, väljendavad koos ma-infinitiivi või noomeniga intensiivset ehk järsku ingressiivsust ehk situatsiooni algust. (Erelt 2013: 78-79) $m a$-infinitiiviga alustamiskonstruktsiooni näited koonduvad järgneva skeemi alla:

AGENT $+\mathrm{V}_{m a \text {-inf }}+$ panema $_{(\text {vormipiiranguid pole })}$

Erinevalt põhjustamiskonstruktsioonist hõlmab alustamiskonstruktsioon vaid ühte sündmust (nt Ta paneb jooksma $>$ Ta jookseb) ja alustamiskonstruktsioonis pole objekti argumenti, keda/mida subjekti argument mõjutaks midagi tegema. Vaadeldavas materjalis esines panema-verb koos selliste $m a$-infinitiivis verbidega nagu plagama, putkama, minema, tulema ja haukuma. Neil juhtudel näitab konstruktsioon kas teatud tüüpi liikumise või häälitsemise algust. Konstruktsiooni ei sobitu aga kõik verbid, näiteks ei öelda *ta paneb jalutama. ma-infinitiivseid alustamiskonstruktsiooni kasutusjuhte ta paneb jōksma ja laulma on oma 1869. aastal ilmunud sõnaraamatus maininud ka Wiedemann (1923: 764). See konstruktsioon on kirjakeeles esinenud üksikute kasutusjuhtudena. 1766. aasta Hupeli tekstis leidunud näide se emma panneb last immetama tekitas küsimuse, kuivõrd see suhestub vormiliselt ja tähenduslikult praeguse alustamiskonstruktsiooniga. Mõnevõrra rohkem hakkas selliseid näiteid ilmuma XX sajandil, aga teiste panema-verbi kasutuste seas jääb selle konstruktsiooni esinemus praeguses keelekasutuses ikkagi vaid ühe protsendi piirimaile.

Eelnevale lisaks võib panema-alustamiskonstruktsioon näidata ka eesmärki, mida esines materjalis vaid üks kord (näide 7). Sel juhul lisandub objekt.

(7) Pooljoostes pani sellega avama väravat. (ILU 1930) 
Resultatiivsete näidete vähesuse ja nimetatud alustamiskonstruktsiooni verbide põhjal võib üldistada, et panema-alustamiskonstruktsioon soosib tegevusverbe (Vendleri TEGEVUSED).

Veel väljendatakse alustamist sellise konstruktsiooniga, milles panemaverbi kõrval esineb nimisõna. Noomen on siis kas illatiivis (nt paneb metsa / linna) või esineb kivinenud kujul (nt paneb jooksu, paneb plehku). Illatiiviga konstruktsioon on ilmselt seostatav panema-verbi omadusega väljendada intensiivset liikumist (vt ekspressiivsusest osas 4), mis toimub mingis suunas ja on orienteeritud lõpp-punktile.

\section{Panema-verbi ekspressiivne kasutus ${ }^{2}$}

Viimase aja keelekasutuses leidub selliseid näiteid, kus panema moodustab ekspressiivse ühendi koos mõne muu sõnaga, enamasti nimisõnaga (nt kellelegi ära panema 'kellegi üle võitu või üleolekut saavutama' (näide 8) ja 'kohta kätte näitama', puusse panema 'millegagi eksima', pirni panema 'midagi üllatavat ütlema') või asendab teisi verbe ning lisab oma kujundliku tähendusega väljendile ekspressiivsust (nt kiirust panema 'kiirust lisama', kanepit panema 'kanepit manustama' (näide 9), (rusikaga) panema 'lööma', hästi paned!'midagi tabavalt tegema/ütlema', (sajaga) panema 'intensiivselt liikuma' ja panema 'sugulises vahekorras olema (mehe kohta)').

(8) Oma hinna juures paneb see pika puuga ära teiste tootjate sama hinnaklassi telefonidele [---] (etTenTen)

(9) [---] panin ka seda kanepit mitu aastat, ja järsku hakkas mälu streikima [---] (etTenTen, naistekas.delfi.ee)

Panema-verb sobitub ka ühenditesse, nagu pidu panema (näide 10) ja naeru panema. Nendega sarnased on Google'ist lisaotsingutega leitud kasutusnäited pausi panema, poppi panema ja tuima panema ning EKSS-is (2009: 76) sisalduvad tvisti panema ja streiki panema. Need on kujundlikud püsiühendid, mille käändsõnaline komponent on ainsuse osastava vormis.

(10) Kas pärast õnnestunud kontserti armastate pidu panna, alkoholi manustada? (etTenTen, www.rada7.ee)

Nimetatud ühendeid seob kestuslik tähendus, mis enamikus näidetes tuleneb peamiselt noomeni tähendusest. Näiteks on paus ja streik pikema kestusega kui vaid hetkelised sündmused. Panema-verbi osa neis ühendites on mõnel juhul, selgelt näiteks ühendites tvisti panema või pidu panema, tegevuse intensiivistamine. Nii seostub ka see rühm ekspressiivsuse väljendamisega, hõlmates mingit tegevust, mida on võimalik või mida tahetakse neutraalsest intensiivsemana esile tuua.

${ }^{2}$ Selle tendentsi selgitamiseks on analüüsitud materjali kõrvale otsitud lisanäiteid korpusest etTenTen ja Google'ist. 
Ilmneb ka panema-verbi esinemine tugiverbikonstruktsioonis. Kadri Muischnek (2005) nimetab tugiverbikonstruktsiooni komponentidena nimisõnafraasi, mis annab konstruktsioonile tegevuse või protsessi tähenduse, ja suhteliselt sisutühja verbi, mis väljendab grammatilist funktsiooni. Näites teevad tööd võib näha, et seda tugiverbikonstruktsiooni on võimalik väljendada ka ühesõnaliselt: töötavad. Vaadates tugiverbilisust pidu panema näitel, saaks selle ühendi (näide 10) sõnastada ümber kestusliku verbiga pidutsema. Nimetatud rühma näidetes võib näha panema-verbi skeemi, kuhu saavad siseneda partitiivi vormis enamasti kestusega sündmusele osutavad noomenid.

Ekspressiivseid kasutusi võiks käsitleda intensiivistava rühmana, mida ei seo mitte tähenduslik või vormiline ühtsus, vaid emfaatiline/ekspressiivne värving. Kuna kõikidel juhtudel pole värving sama intensiivsusastmega, siis võib eri kasutusjuhud paigutada skaalale, mille ühes otsas on intensiivsema ja teises neutraalsema värvinguga kasutused. Ekspressiivsed kasutusjuhud võib jagada eri tähendusrühmadesse ehk teisisõnu võiks eri tähendusrühmades nimetada ekspressiivseid kasutusjuhte. Kuigi selliseid näiteid on panemaverbi kasutustes tervikuna võrdlemisi vähe, tuleks ekspressiivse kasutuse tendentsile selle produktiivse kasutuse tõttu siiski eraldi tähelepanu osutada. Enamasti leiduvad need näited veebilehtede korpuse etTenTen materjalis. Sinna kuuluvad muuhulgas ka blogide või foorumite tekstid, mis on sageli kõnekeelsed. Samuti leiab seda tüüpi kasutusjuhte Google'i päringute abil vabama stiiliga žanridest, näiteks kommentaariumidest.

Ekspressiivne kasutus on mõnikord situatsioonikeskne, näiteks panemaverbi löömistähendus lauses Pane talle! on mõistetav vaid kindlas kontekstis. Ekspressiivsete kasutuste jagamisel laiadesse tähendusrühmadesse tuleb siiski arvestada, et neisse kuuludes ei sobitu kasutusjuhud sinna mitte kõige otsesemas tähenduses, vaid kujundlikena. Lisaks eelnevalt nimetatud kasutustele on ekspressiivsus ka alustamiskonstruktsiooni näidetes (nt ajama panema ja metsa panema). Polüseemne panema-verb võimaldab alustamist väljendada neutraalsest intensiivsemalt (nt koerad hakkasid haukuma / koerad panid haukuma). Panema-põhjustamiskonstruktsioonis on panema aga põhjustamissündmuse osa ega mõjuta sellisena tulemussündmuse intensiivsust. Seetõttu ei mõju ka põhjustamiskonstruktsiooniga tervikuna väljendatu ekspressiivsena.

Võib arutleda, kust selline panema-verbi omadus pärineb. Ühest vastust on raske anda, kuid suures osas näidetes võib seda seostada löömistähendusega. Ühendis pihta panema ilmneb see selgelt, aga ka kirjakeeles laiemalt kinnistunud ühend vastu panema kannab endas löömis- või tõrjumistähendust. Võib oletada, et uuemad ekspressiivsed kasutused on tekkinud eelnevaid kasutusi osaliselt matkides ning saavutanud uue iseseisvuse ja tähendusegi.

\section{Sildkonstruktsioonid ja tähendusseosed}

Panema-verbi tähendusi saab kirjeldada ühekaupa, nagu eelmistes jaotistes tehtud, aga nende vahel on ka palju seoseid. Mõnda kasutusjuhtu ei saagi ainult ühte või teise tähendusrühma liigitada, st need kuuluvad korraga kahte või rohkemasse rühma. Suurem osa sildkonstruktsioonidest kannab sama- 
aegselt asetamis- ja põhjustamistähendust. Näiteks kui pesu pannakse likku, siis ühelt poolt see asetatakse kuhugi, teiselt poolt põhjustatakse leotamisprotsess. Kui aga näiteks kedagi pannakse klassi ette, vangi või kooli, siis on põimunud asetamis- ja määramistähendus, st keegi määrab kellegi mingisse paika. Kuigi sildkonstruktsioonide tähendusi saab nimetada, ei saa neid kasutuses üksteisest eraldada. Tähenduste koosesinemine näitab üleminekute sujuvust polüseemse sõna tähenduste vahel.

Joonisel 2 on kujutatud panema-verbi leksikaalsete ja grammatiliste tähendusrühmade omavahelised seosed. Iga tähendusrühma alla kuulub väiksem või suurem hulk panema-verbi kitsamaid kasutusi, sh kuuluvad tähendusrühmadesse ka kujundlikud kasutusjuhud. Pideva joonega on tähistatud panema-verbi põhitähendused ja katkendliku joonega mitmese tähendusega sildkonstruktsioonid. Jooned rühmade vahel näitavad tähendusseoseid: keskne asetamistähendus on seotud kõikide teiste tähendustega.

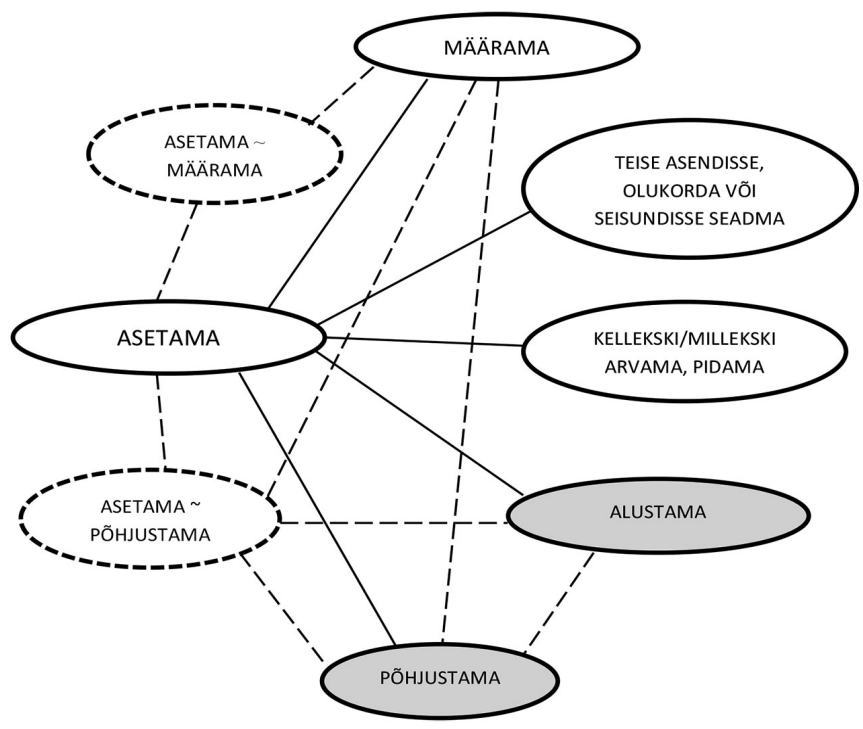

J o on is 2. Panema-verbi tähendusrühmad.

Eraldi tuleks selgitada põhjustamistähenduse seost teiste tähendustega. Põhjustamistähendus on seotud nii asetamis-, määramis- kui ka alustamistähendusega. Põhjustamist saab seostada asetamisega mitmel viisil. Esiteks seostuvad need tähendused sildkonstruktsioonide kaudu, nt eelnevalt nimetatud likku panema näide. Teiseks, panema-verbi asetamistähendus osutab mingi objekti asukoha muutusele, sobitudes sellega seisundi/olukorra vms muutust osutavasse põhjustamiskonstruktsiooni (vt verbide sobivuse kohta konstruktsioonidesse Goldberg 1995: 59-66). Lisaks viitab asetamisele ka see, et $m a$-infinitiiv on ajalooliselt väljendanud sisseütlevat käänet (Saukkonen 1965). Lauses laps pannakse istuma on läbinähtav ka asetamistähendus, eriti 
kui mõelda juurde koht, nt laps pannakse toolile istuma. Määramisega seostub põhjustamine sel viisil, et agendiline MõJUTAJA on samas ka määraja. Põhjustamine on tugevalt seotud alustamisega, kuna millegi põhjustamine ongi samaaegselt millegi algus.

\section{Kokkuvõte}

Panema-verbi kasutust eesti kirjakeeles uuriti XVI-XXI sajandi korpusmaterjali põhjal. Kokkuvõtlikult saab panema-verbi leksikaalsed tähendused jagada neljaks rühmaks: '(ruumis) objekti asukohta muutma' (nt peale panema), 'teise asendisse, olukorda või seisundisse seadma' (nt kinni panema), 'määrama' (nt hindeks panema) ja 'kellekski/millekski/mingisuguseks pidama, arvama' (nt pahaks panema). Grammatilised tähendused on põhjustamistähendus (nt ma panen vee keema) ja alustamistähendus (nt nad panevad plagama).

Kui panema-verbi otsene asetamistähendus on läbi sajandite olnud sagedasim tähendus, siis selle verbi grammatilisi kasutusi XVI-XVII sajandi saksamõjulistes kirjakeele tekstides veel ei leidunud. Siiski võib esimeste panema-põhjustamiskonstruktsiooni varieeruvate näidete põhjal oletada, et rahvakeeles kasutati seda konstruktsiooni ka juba enne XVIII sajandit. Panema-põhjustamiskonstruktsioon ei ole üle võetud saksa keelest. Kui põhjustamistähendus on hilisemates tekstides sage (XIX-XXI sajandil 10-15\% kasutusjuhtudest), siis alustamistähenduse osakaal on läbi kirjakeele ajaloo olnud väike (ühe protsendi ringis).

XXI sajandil on keelde tulnud üha rohkem selliseid panema-verbi kõnekeelelähedasi kasutusjuhte, milles panema lisab erinevatele ühenditele väljendusrikkust või asendab teisi verbe (nt ära panema ja kiirust panema). Kuuludes eri tähendusrühmadesse ja olles varieeruvad ka vormiliselt, on neis siiski ühine omadus (siinses töös on oletatud, et see võib olla seotud kõige rohkem löömistähendusega), mille põhjal saab neid iseloomustada kui ekspressiivseid kasutusi. Ka sellistes näidetes nagu pidu panema ja naeru panema võib rääkida ekspressiivsusest.

Sagedasemad panema-verbiühendid on näiteks kirja panema ja tähele panema, kuid sageduse poolest ei jää nendest kaugele esimene grammatiline kasutusjuht mõtlema panema. Kõige sagedasemad ma-infinitiivsed tegusõnad panema-põhjustamiskonstruktsioonis on mõtlema ja imestama. Samuti esilduvad verbiühendid maksma panema 'kehtestama' ja käima panema 'käivitama'.

Panema-põhjustamiskonstruktsiooni analüüsis toodi välja levinumad kausatiivikonstruktsiooni tüübid. Kõikidesse kasutusjuhtudesse kuuluvad vormiliselt järgmised komponendid: nominatiivis subjekt; nominatiivis, genitiivis või partitiivis objekt ning kaheosaline predikaat (panema-verb ja mainfinitiivis verb), nt see muusika (nominatiivis subjekt) paneb laulma (kaheosaline predikaat) kõik inimesed (nominatiivis objekt). Kuigi põhjustamiskonstruktsioonides ilmnes suur semantiline varieeruvus (21 erinevat põhjustamiskonstruktsiooni tüüpi), esinesid teistest mõnevõrra sagedamini järgmised konstruktsioonitüübid: AGENT-PATSIENT-PROTSESS (15,7\%, nt ta paneb seened hapnema), JÕUD-PATSIENT-PROTSESS (14,8 \%, nt vesi pani puid hallitama), AGENT- 
PATSIENT-TEGEVUS $(12,7 \%$, nt politseinik paneb ta rääkima) ja AGENT-PATSIENTSEISUND (12\%, nt ta pani hobuse end austama).

Panema-verbi leksikaalsete tähenduste kõrval on selle keskseim grammatiline kasutus seega täielikult produktiivne panema-põhjustamiskonstruktsioon, mille kõrval esineb mitteproduktiivne alustamist väljendav faasikonstruktsioon. Panema-verbi iseloomustamisel tuleb esile tõsta ka selle arvukaid (grammatiseerumisega kaasnevaid) kujundlikke kasutusi ning sealhulgas sobivust tugiverbikonstruktsiooni. Nagu keel laiemalt, on ka polüseemne panema-verb oma kasutuses ühtaegu püsiv ja muutuv.

\section{Allikaviited}

Eesti kirjakeele korpus. http://www.cl.ut.ee/korpused/kasutajaliides/ (10. XII 2014).

etTenTen korpus. http://www2.keeleveeb.ee/dict/corpus/ettenten/ (21. VIII 2015).

VAKK = Vana kirjakeele korpus. http://www.murre.ut.ee/vakkur/Korpused/ (1. XI 2013; 15. XI 2014).

Sketch Engine. https://www.sketchengine.co.uk/ (27. XI 2015).

Ühendkorpus (leitav Sketch Engine’i kaudu). https://www.sketchengine.co.uk/ (27. XI 2015).

\section{Kirjandus}

B arlow, Michael, Kemmer, Suzanne 2000. Usage Based Models of Language. Stanford: CSLI Publications.

Dix on, Robert M. W. 2000. A typology of causatives: form, syntax and meaning. - Changing Valency: Case Studies in Transitivity. Toim R. M. W. Dixon, Alexandra Y. Aikhenvald. Cambridge: Cambridge University Press, lk 30-83.

EES = Eesti etümoloogia sõnaraamat. Peatoim Iris Metsmägi. Toim I. Metsmägi, Meeli Sedrik, Sven-Erik Soosaar. Tallinn: Eesti Keele Sihtasutus, Eesti Keele Instituut, 2012.

EKSS = Eesti keele seletav sõnaraamat. 4: P-R. „Eesti kirjakeele seletava sõnaraamatu" 2., täiendatud ja parandatud trükk. Toim Margit Langemets, Mai Tiits, Tiia Valdre, Leidi Veskis, Ülle Viks, Piret Voll. Tallinn: Eesti Keele Sihtasutus, 2009.

Erelt, Mati 2001. Some notes on the grammaticalization of the verb pidama in Estonian. - Estonian: Typological Studies V. (Tartu Ülikooli eesti keele õppetooli toimetised 18.) Toim M. Erelt. Tartu, lk 7-25.

Erelt, Mati 2013. Eesti keele lauseõpetus. Sissejuhatus, öeldis. (Tartu Ülikooli eesti keele osakonna preprindid 4.) Tartu.

Goldberg, Adele E. 1995. Constructions: A Construction Grammar Approach to Argument Structure. Chicago: The University of Chicago Press.

Habicht, Külli, Penja m, Pille, Tragel, Ilona 2010. Kas tahtma tahab abiverbiks? - Keele rajad. Pühendusteos professor Helle Metslangi 60. sünnipäevaks. Toim Urmas Sutrop, I. Tragel. ESUKA-JEFUL, kd 1, nr 1-2, lk 115-146. 
Habicht, Külli, Tragel, Ilona 2012. Grammaticalization of Estonian saama 'to get'. - Linguistics, kd 50, nr 6, lk 1371-1411.

H a bi c h t, Külli, Pi ir oj a, Piret, Tr a g e l, Ilona 2015. Eesti võtma-tuleviku lugu. - Emakeele Seltsi aastaraamat 60 (2014). Tallinn: Teaduste Akadeemia Kirjastus, lk 19-50.

Hein e, Bernd 1993. Auxiliaries. Cognitive Forces and Grammaticalization. New York: Oxford University Press.

Heine, Bernd, Kuteva, Tania 2002. World Lexicon of Grammaticalization. Cambridge: Cambridge University Press.

Heine, Bernd, Kuteva, Tania 2006. The Changing Languages of Europe. New York: Oxford University Press.

Hopper, Paul J., Traugott, Elizabeth Closs 1993. Grammaticalization. (Cambridge Textbooks in Linguistics.) Cambridge: Cambridge University Press.

Kasik, Reet 2001. Analytic causatives in Estonian. - Estonian: Typological Studies V. (Tartu Ülikooli eesti keele õppetooli toimetised 18.) Toim Mati Erelt. Tartu, lk 77-122.

Ka sik, Reet 2015. Sõnamoodustus. (Eesti keele varamu I.) Tartu Ülikool: Tartu Ülikooli Kirjastus.

Kilgarriff, Adam, Rychlý, Pavel, Smr, Pavel, Tugwell, David 2004. The Sketch Engine. - Proceedings of the $11^{\text {th }}$ EURALEX international congress. Toim G. Williams, S. Vessier. Lorient, France: Université de Bretagne Sud, lk $105-115$.

Maripu u, Kristiina 2012. Saama-verbi tähendustest ja funktsioonidest 16.-19. sajandi põhjaeesti kirjakeeles. Bakalaureusetöö. Käsikiri Tartu Ülikooli eesti keele õppetoolis.

Matthew s, Peter H. 1997. The Concise Oxford Dictionary of Linguistics. OxfordNew York: Oxford University Press.

Mu is chnek, Kadri 2005. Eesti keele tugiverbid ja nende mõju lauseehitusele. - Emakeele Seltsi aastaraamat 50 (2004). Tallinn: Teaduste Akadeemia Kirjastus, lk 11-38.

Pajun en, Anneli 1999. Suomen verbirektiosta. Åbo: Åbo Akademis tryckeri.

Penjam, Pille 2008. Eesti kirjakeele $d a$ - ja $m a$-infinitiiviga konstruktsioonid. (Dissertationes philologiae Estonicae Universitatis Tartuensis 23.) Tartu: Tartu Ülikooli kirjastus.

R a vi n, Yael, Le a c o ck, Claudia 2000. Polysemy: An overview. - Polysemy. Theoretical and Computational Approaches. Toim Y. Ravin, C. Leacock. Oxford: Oxford University Press, lk 1-29.

S a ukk on en, Pauli 1965. Itämerensuomalaisten kielten tulosijainfinitiivirakenteiden historiaa I: Johdanto. Adverbiaali infinitiivi. (Suomalais-Ugrilaisen Seuran toimituksia 137.) Helsinki.

Tomson, Kairit 2014. Panema-verb ja selle grammatilised konstruktsioonid 16.-18. sajandi eesti kirjakeeles. Bakalaureusetöö. Tartu: Tartu Ülikool. http:// hdl.handle.net/10062/43918

Tomson, Kairit 2016. Panema-verbi polüseemia ja kasutus grammatilistes konstruktsioonides. Magistritöö. Tartu: Tartu Ülikool. http://hdl.handle. net/10062/51758

Tr a g e l, Ilona 2003. Eesti keele tuumverbid. (Dissertationes linguisticae Universitatis Tartuensis 3.) Tartu: Tartu Ülikooli kirjastus. 
Tr a ge l, Ilona, Ha bi cht, Külli 2017. Saama-verb grammatilistes konstruktsioonides. - Keel ja Kirjandus, nr 1, lk 22-40.

Van Valin, Robert D. Jr. 2001. An Introduction to Syntax. Cambridge: Cambridge University Press.

Vendler, Zeno 1957. Verbs and times. - The Philosophical Review, kd 66, nr 2, lk 143-160.

W i e d e m a n n, Ferdinand Johann 1923. Eesti-saksa sõnaraamat. Kolmas, muutmata trükk teisest, Jakob Hurda redigeeritud väljaandest. Tartu: Eesti Kirjanduse Seltsi kirjastus.

\section{The verb panema 'put' and its grammatical functions}

Keywords: polysemy, grammaticalization, diachronic linguistics, construction, causation, phasal meaning, core verbs, Estonian

The article analyses the use of the Estonian core verb panema 'put' in written Estonian. It describes the polysemy of the verb panema and focuses on its grammatical constructions. Numerous lexical and grammatical usages of panema are presented as a network of meanings and functions.

The material for examining the verb panema was collected from corpora containing texts from the 16th century until the present. Over 3000 instances of the verb panema were included in the study. The panema instances were divided into meaning groups. Its lexical meanings are 'to change the location of an object in space' (the most frequent meaning in each period), 'to set (something or someone) in another position, state or situation', 'to appoint' and 'to consider, to take (someone) for'. The verb panema appears in the causative construction, expressing causativity (CAUSER + panema + CAUSEE $+\mathrm{V}_{m a-\text {-inf }}$ ), and in the phasal construction, expressing an initial phase (AGENT $+\mathrm{V}_{\text {ma-inf }}+$ panema; or in form of fixed expressions). The lexical meaning 'to change the location of an object in space' is present, to a lesser or greater extent, in every meaning. A remarkable number of panema cases are figurative.

The analysis of the panema-causative, which nowadays makes up 10-15 per cent of all panema cases, brings out a wide range of construction types. The panema-causative consists of a subject, an object, the verb panema and a -ma infinitive. The components of the construction have different semantic roles, which combine with each other in several ways. Altogether, there are 21 different types of the panema-causative, the most frequent ones being AGENT-PATIENT-PROCESS (15.7 per cent), FORCE-PATIENT-PROCESS (14.8 per cent), AGENT-PATIENT-ACTION (12.7 per cent) and AGENT-PATIENT-STATE (12.0 per cent). The phasal construction tends to be less frequent in texts, remaining around one per cent. Recently, various cases in which the verb panema adds expressivity to a fixed expression or replaces other verbs, have appeared.

Kairit Tomson (b. 1986), MA, University of Tartu, Institute of Estonian and General Lingvistics, PhD student, cayrit@gmail.com 